\title{
Managing A Franchise System: A Literature Review And A Synthesis
}

Ramon Diaz-Bernardo, IE University, Spain

\begin{abstract}
The article reviews the line of franchising research known as managing a franchise system. The main research topics that can be found in this line of research are conflicts between franchisor and franchisee, the balance of power in the franchising system, and managing the franchisorfranchisee relationship. The author reviews some of the existing literature related to managing franchising systems and provides a synthesis and some recommendations to develop better franchising systems.
\end{abstract}

Keywords: Franchising; Conflicts; Power; Relationships

\section{INTRODUCTION}

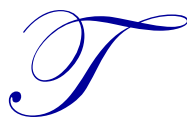

he analysis of the operation of a franchise system has been approached, primarily from the branch of marketing known as distribution channels or marketing channels. In this regard, the franchise system is treated as a distribution channel, using the dimensions traditionally used in the literature on distribution channels - conflict, power, and relationship (Stern \& El-Ansary, 1988).

Conflict is understood to be inherent in the franchise system (Spinelli \& Birley, 1998). Despite the fact that the franchising contract aligns the objectives of franchisor and franchisee, each part also has their particular agenda. When the particular interests of franchisor and franchisee interfere, the situation derives in conflict. One of the sources of conflict most recurrently observed in franchised systems is the divergence of goals derived from the royalty system. As the royalties the franchisee pays to the franchisor are based on sales, not profits, the franchisor normally tries to increase the volume of the franchisee's sales, whereas the franchisee may prefer to sell products that generate higher profit.

Spinelli and Birley (1998) illustrate that the franchisee's perception of the franchisor's level of cooperation, communication, coordination, and commitment can reduce the incongruence of their goals and the level of conflict.

Power is also a central dimension in the literature on franchising. The power asymmetry between the franchisor and the franchisee has been discussed with the objective of promoting and developing legislation to protect franchisees from abuses of power by the franchisor (Fern, 1995). The franchisee's dependence on the franchisor confers upon the latter a source of power to control the franchisee and obtain his or her cooperation. Hunt and Nevin (1974) point out that the franchisee's cooperation can be achieved in three ways: (1) persuading the franchisee of the value of their relationship with the franchisor, (2) using coercive power to manipulate the franchisee's actions, or (3) using noncoercive means, such as franchisor support.

Franchisees are more willing to cooperate when they perceive themselves as forming part of the system's decision-making structure and when the uncertainty over the outcome of their business is reduced by the franchisor's support (Guiltinan, Rejab, \& Rodgers, 1980). Schul, Pride, and Little (1983), however, find that franchisors that use an executive leadership style are more effective than the ones that use a participative leadership style when it comes to reducing conflict and increasing cooperation.

From a more "relational" point of view, Strutton, Pelton, and Lumpkin (1995) explain how the ability of the franchisor to maintain good relationships with the franchisees over the long term has a fundamental influence on the 
success of the system. These authors maintain that solidarity is the behavioral norm, which maintains the cohesion between the franchisee and franchisor, and the degree of solidarity is determined by the psychological climate between the franchisee and the franchisor (depending on the perceptions of justice, cohesion, innovation, and autonomy). Anderson and Weitz (1989) point to the importance of communication and trust in order to create interpersonal relationships between the parties that form the basis of a stable long-term relationship between the franchisor and the franchisee.

Despite the importance of the relationship in a system, such as franchising, where contracts are, by definition, incomplete, there has been little empirical research seeking to link the quality of the franchiseefranchisor relationship with the performance of the system. The work of Morrison (1997) studies the relationship between franchisee satisfaction and performance measured in terms of economic results, organizational commitment, relationships with the franchisor, and intention to remain in the system. Surprisingly, the results show a very weak (and moreover, negative) relationship between the franchisee-franchisor relationship and economic performance, although the methodology used does not allow causality to be established. Wood and Kiecker (1995) analyze the influence of the franchisee-franchisor relationship on performance from a theoretical point of view. Although they do not test their propositions empirically, they link the management style of the franchisor, the franchisee-franchisor relationship, and the franchisee-customer relationship with the performance of the system as a whole.

Strutton et al. (1995) indicate that the ability of the franchisor to maintain good relationships with its franchisees over the long term has an important influence on the success of the system. Madhok and Tallman (1998) contend that developing a quality relationship between the parties is not only important for the survival of the system but also is a difficult asset to copy, as well as an intrinsic source of value for the organization. Therefore, it seems to be a consensus among researchers about the importance of the relationships between franchisor and franchisee. The development of a good relationship between franchisee and franchisor is not only important, but it is a strategic capability for the success of the franchise system.

Following Kaufmann and Dant (1992), the quality of the relationship between the franchisee and the franchisor can be defined through four key dimensions: (1) long-term focus on the relationship, (2) appropriate use of power, (3) flexibility in the relationship, and (4) mutuality in the relationship. The first dimension - long-term focus - measures the degree to which the relationship between the franchisee and the franchisor is perceived by the parties as something more important than individual transactions. The second dimension - appropriate use of power implies that, despite the fact that the contract establishes the power that legitimately corresponds to each part in a relational structure of governance, the parties will voluntarily limit the use of their power in order to preserve the relationship. The third dimension - flexibility, implies adaptation to change. Thus, when changes take place in the environment, both parties must adapt their behaviors to the new circumstances in order to preserve the relationship, despite the contractual provisions. The fourth dimension - mutuality - reflects the expectations both parties have in terms of the reciprocity of their exchanges over the long term. For example, in transactional governance systems, the parties require a positive balance from each individual transaction, considering each transaction as if it were the last. On the other hand, in relational systems, the parties expect a positive balance to emerge from the relationship over the long term.

A good relationship between franchisor and franchisee not only reduces opportunistic behaviors - and therefore the need for controls and safeguards - but also offers an opportunity for obtaining greater profitability through a more effective combination of the resources contributed by the franchisee and the franchisor. We have found that numerous franchise chains were more willing to invest in tangible assets (such as new premises and equipment), where calculating cost-benefit ratios is straightforward, than in intangible assets (such as the franchisee-franchisor relationship), where the cost-benefit ratio is much harder to determine. We believe that this is a short-term view, and our recommendation is that chains should invest resources in building solid relationships with their franchisees. Although the process of building a relationship of this kind is slow and will probably take time to bear fruit, the long-term benefits should more than outweigh the costs incurred. 


\section{CONCLUSION}

In this article we have reviewed the line of research known as managing a franchise system. Within this line of investigation, there are some very interesting questions, such as how to deal with the inevitable conflicts that arise in a franchising relationship and what is the best leadership style in a franchising organization - executive leadership style or participative leadership style. Another issue that seems to have a clear influence on the performance of a franchised chain is the relationship between franchisor and franchisee. The question here is how to build a good relationship between franchisor and franchisee, and the answer can be summarized in four final recommendations for the franchisor - adopt a long-term approach to the relationship, use power appropriately, be flexible in the relationship with the franchisee, and show reciprocity and mutuality in franchisor-franchisee exchanges.

\section{AUTHOR INFORMATION}

Professor Diaz-Bernardo holds a degree in Engineering from Universidad de Oviedo (Spain), an MSc in Engineering by the University of Nottingham, an MBA from ESDEN Business School and he is a Doctor in Business Administration (Ph.D.) from IESE Business School. He is an active member of the Academy of Marketing and the American Marketing Association, where he is a regular contributor at their annual meetings. Professor DiazBernardo serves regularly as a consultant for the United Nations World Tourism Organization, especially for the UNWTO Asia/Pacific Representation. E-mail: ramon.diaz@ie.edu

\section{REFERENCES}

1. Anderson, E., \& Weitz, B. (1989). Determinants of continuity in conventional industrial channel dyads. Marketing Science, 8, 310-323.

2. Fern, M. D. (1995). Franchising. International Financial Law Review, Issue: United States Legal Guide Corporate Activity, pp. 25-29. Volume 10, pp 25-29

3. Guiltinan, J. P., Rejab, I. B., \& Rodgers, W. C. (1980). Factors influencing coordination in franchise channel. Journal of Retailing, 56, 41-58.

4. Hunt, S. D., \& Nevin, J. R. (1974). Power in a channel of distribution: Sources and consequences. Journal of Marketing Research, 11, 186-193.

5. Kaufmann, P. J., \& Dant, R. P. (1992). The dimensions of commercial exchange. Marketing Letters, 3(2), $171-185$.

6. Madhok, A., \& Tallman, S. B. (1998). Resources transactions and rents: Managing value through interfirm collaborative relationships. Organization Science, 9(3), 326-339.

7. Morrison, K. A. (1997). How franchisee job satisfaction and personality affects performance, organizational commitment, franchisor relations, and intention to remain. Journal of Small Business Management, 35, 39-67.

8. Schul, P. L., Pride, W. M., \& Little, T. L. (1983). The impact of channel leadership behavior on intrachannel conflict. Journal of Marketing, 47, 21-34.

9. Spinelli, S., \& Birley, S. (1998). An empirical evaluation of conflict in the franchise system. British Journal of Management, 9, 301-325.

10. Stern, L. W., \& El-Ansary, A. L. (1988). Marketing channels (3rd ed.). Englewood Cliffs, NJ: Prentice Hall.

11. Strutton, D., Pelton, L. E., \& Lumpkin, J. R. (1995). Psychological climate in franchising system channels and franchisor-franchisee solidarity. Journal of Business Research, 34, 81-91.

12. Wood, V. R., \& Kiecker, P. (1995). A contingency model of franchise management: The role of leadership style and perceived expertise. Journal of Marketing Channels, 4(3), 1-31. 


\section{NOTES}

